\begin{tabular}{|c|c|c|}
\hline Beitr. Ent. & Berlin & ISSN 0005-805X \\
\hline $\mathbf{5 0}(2000) 1$ & S. $129-150$ & 11.04 .2000 \\
\hline
\end{tabular}

\title{
Taxonomic study of the genus Ceromya ROBINEAU-DESVOIDY of Japan
}

\section{(Diptera: Tachinidae) ${ }^{1}$}

With 65 figures

\section{TAKUII TACHI and HIROSHI SHIMA}

\section{Summary}

The Japanese species of the genus Ceromya RoBINEAU-DESvOIDY are reviewed. Ten species are recognized, eight of which are classified in three species groups: the bicolor group, flaviseta group and silacea group. Two species, C. cothurnata and C. luteola, are treated as incertae sedis. The autapomorphies of these species groups are redefined and characters illustrated: bicolor group - male genitalia: gonopod with lateral edge projected outwardly, flaviseta group - male genitalia: distiphallus in lateral view almost sclerotized, bearing small spinules ventrally, and lateral portion largely membranous, silacea group - male genitalia: distiphallus in lateral view broad, with posterolateral arm, and deeply bifurcated at apex in dorsal view; female terminalia: abdominal sterna 6-7 with minute setulae; first instar larva: labrum sharp and narrow apically. The following six species are described from Japan: $C$. cothurnata sp. n., C. glaucescens sp. n., C. helvola sp. n., C. kurahashii sp. n., C. luteola sp. n., and C. prominula sp. n. A key to the Japanese species is provided.

\section{Zusammenfassung}

Eine Übersicht über die japanischen Arten der Gattung Ceromya RoBINEAU-DEsvoIDY wird gegeben. Zehn Arten werden als gültig anerkannt, wovon acht in die bicolor-, flaviseta- und silacea-Gruppe plaziert werden. Zwei Arten, $C$. cothurnata und C. luteola, werden als incertae sedis betrachtet. Die Autapomorphien der Arten-Gruppen werden neu definiert und die Merkmale abgebildet. Die folgenden sechs neuen Arten werden aus Japan beschrieben: $C$. cothurnata sp. n., C. glaucescens sp. n., C. helvola sp. n., C. kurahashii sp. n., C. luteola sp. n. und C. prominula sp. n. Ein Bestimmungsschlüssel für die japanischen Arten wird vorgelegt.

\section{Key words}

Tachinidae, Siphonini, Ceromya, species group, taxonomy, Japan.

\section{Introduction}

The genus Ceromya RoBINEAU-DEsvoIDY, 1830 belongs to the tribe Siphonini of the subfamily Tachininae (Diptera: Tachinidae), and comprises fifty-one species widely distributed in the world. The genus is characterized by the following combination of external characters: lower proepimeral seta absent or hair-like and directed upwards; katepisternum lacking a row

${ }^{1}$ Contribution from the Biosystematics Laboratory, Graduate School of Social and Cultural Studies, Kyushu University (No. 40). 
of hairs anterior to the mid coxa; vein $\mathrm{A}_{1}+\mathrm{CuA}_{2}$ not reaching wing margin; preapical anterodorsal seta on fore tibia distinctly shorter than preapical dorsal seta. The monophyly of this genus has so far not yet been established among the Siphonini (ANDERSEN, 1996; O'HARA, 1994) and its systematic position remains under discussion. O'HARA (1989) considered its systematic position as unclear in the tribe Siphonini, while ANDERSEN (1996) mentioned that this genus is closely related to Goniocera BRAUER and BERGENSTAMM based on male and female features.

MALLOCH $(1926,1930,1935)$ described twenty-nine species as belonging to Actia from the Philippines and Malaysia, but only eight of them were assigned to the genus in the contemporary concept of the genus (MESNIL, 1963; CROSSKEY, 1976, 1977; O'HARA, 1989). Actia magnicornis MALlOCH, 1930 was transferred to Ceromya by MESNIL (1. c.), but O'HARA (1. c.) returned it to Actia ROBINEAU-DESVOIDY. MESNIL $(1953,1957)$ described six new species of Ceromya and three of Siphona and Actia from Burma, China, and India. The latter species were later transferred to Ceromya (CROSSKEY, 1976). SHIMA (1970) noted Japanese Siphonini, and added one species to the genus. RICHTER (1993) recorded three species of Ceromya, including one new species, from Transbaikalia and the Far East. O'HARA (1994) revised the Nearctic species of this genus and reported nine species including four new species. ANDERSEN (1996) revised the European species of Siphonini and recorded seven species of Ceromya from Europe.

O'HARA (1989) divided the genus Ceromya into Ceromya s. str. and C. silacea group based on features of the male genitalia and 1st instar larva. O'HARA (1994) later recognized three species groups (americana, bicolor, and flaviseta groups) in Ceromya s. str. for all Nearctic and four Palearctic species. However, ANDERSEN (1996) only recognized the monophyly of O'HARA's americana group.

Currently, four species of Ceromya are known from Japan: Ceromya dorsigera HERTING, $C$. pendleburyi (MAlloch), C. pruinosa SHIMA, C. silacea (MEIGEN) (HERTING, 1984; SHIMA, 1970). In the present work we recognize ten species of the genus including six new species from Japan. Descriptions and redescriptions of these species are given and the male and female genitalia are illustrated. A key to Japanese species is provided. We follow ANDERSEN's concept of the genus Ceromya, but maintain the recognition of O'HARA's species groups because the monophyly of each group was shown to be supported by apomorphic characters.

Two species, C. cothurnata and C. luteola, can not be assigned to any of the above groups because of their peculiar features. They are treated as incertae sedis until the Asian and Oriental fauna are studied in more detail.

\section{Materials and Methods}

Materials studied were mainly from the collection of the Biosystematics Laboratory, Kyushu University (BLKU). Additional specimens were from the following collections: National Institute of Agro-Environmental Sciences, Tsukuba, Japan (NIAES); Systematic Entomology, Faculty of Agriculture, Hokkaido University, Sapporo, Japan (SEHU); Staatliches Museum für Naturkunde, Stuttgart, Germany (SMNS); Deutsches Entomologisches Institut, Eberswalde, Germany (DEI).

Measurements and terminology are the same as stated in our previous paper (TACHI \& SHIMA, 1998). Terminology of the larva follows O'HARA (1988). New distributional records are marked with an asterisk. 


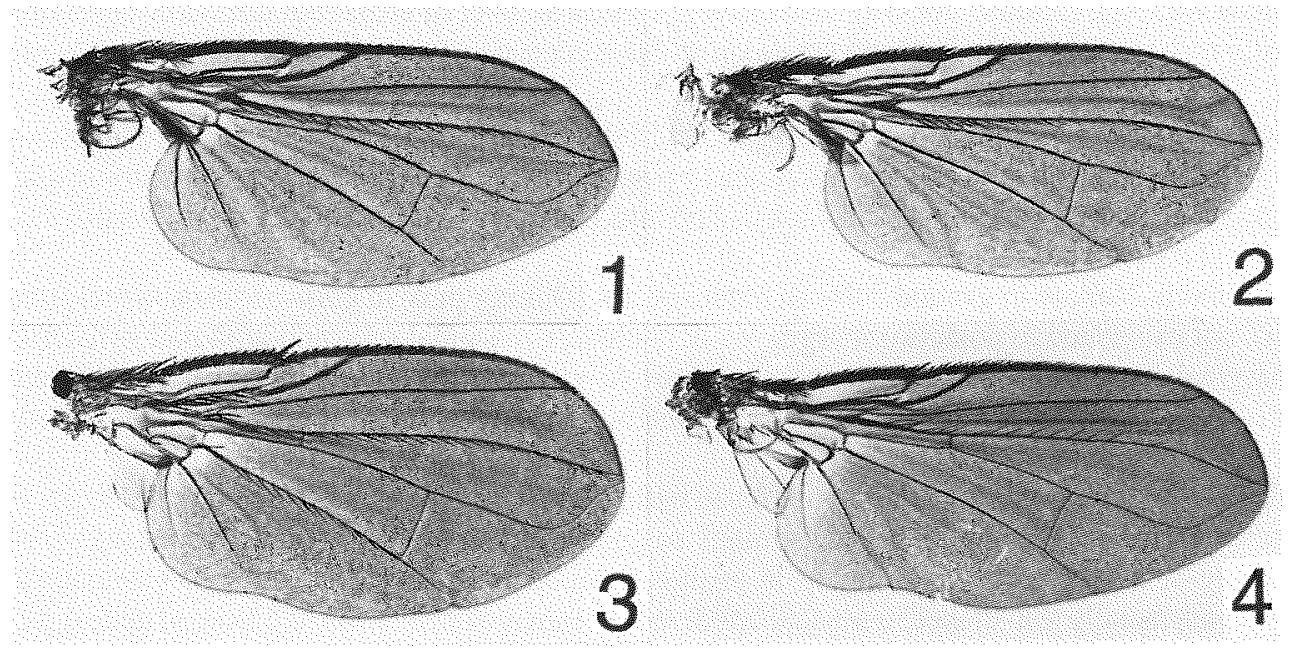

Figs 1-4. Wings. - 1. C. helvola; 2. C. pendleburyi; 3. C. silacea; 4. C. cothurnata.

\section{Systematics}

\section{Genus Ceromya RobINEAU-DesvoIDY}

Ceromya RoBINEAU-DeSvoIDY, 1830: 86. Type species, Ceromya testacea RoBINEAU-DesvoIDY, 1830 (designated by COQUILLETT, 1910: 520)= Tachina bicolor MEIGEN, 1824.

See ANDERSEN (1996) for complete list of synonymies.

\section{Diagnostic characters of Japanese species}

Head. Eye small to large in male, female subequal to or slightly smaller than male; ocellar seta strong; fronto-orbital plate with some fine setae; 2 proclinate orbital setae in both sexes, anterior proclinate orbital seta longer than or subequal in length to posterior one; anterior reclinate orbital seta nearly at middle of fronto-orbital plate or slightly posterior in profile (on anterior 1/3 of fronto-orbital plate in silacea), anterior seta 1.5-2.5 times as long as posterior one; 5 frontal setae in most species (3-4 setae in silacea group); upper occiput and postgena with some fine white setae, only many short black setae in glaucescens; antenna with 1st flagellomere markedly varied, linear to broad, male 1st flagellomere usually wider than in female; 1 st aristomere very short, 2 nd aristomere varied, short to somewhat elongate, 3rd aristomere relatively long, thickened to basal half, with short pubescence; palpus normal; prementum relatively short, 3-4 times as long as wide; labella pad-like.

Thorax. Dorsum yellow or gray; scutellum yellow in most species. Three postpronotal setae in straight line; $2-3+4 \mathrm{ac}, 3+3-4 \mathrm{dc}, 1+3 \mathrm{ia}$; scutellum with short fine apical setae, subapical setae strong, 2-2.6 times as long as scutellum, lateral and basal setae present; distance between bases of subapical setae subequal in length to that between basal and subapical setae of same side; lower proepimeral seta absent or hair-like and directed upward; $2+1$ katepisternal setae, lower seta weaker and shorter than upper anterior one (subequal in length to anterior one in glaucescens); katepisternum bare anterior to mid coxa; prosternum setulose.

Wing. Hyaline; tegula black, reddish brown or light yellow; basicosta yellow or orange. $\mathrm{R}_{1}$ bare or setulose dorsally on apical $1 / 2$ or along entire length, bare ventrally or setulose on 
apical $1 / 3 ; \mathrm{R}_{4+5}$ setulose dorsally to crossvein $\mathrm{r}-\mathrm{m}$ or to level of crossvein dm-cu or nearly to wing margin, with only 1 strong setula on its base ventrally; $\mathrm{CuA}_{1}$ setulose dorsally or bare; $\mathrm{A}_{1}+\mathrm{CuA}$ not reaching wing margin.

Legs. Yellow in ground color in most species (outer surface of fore femur dark gray in glaucescens). Fore tibia with 3-4 ad, 0-3 pd and $1 \mathrm{p}$ setae; mid femur with 2 ad setae at middle and 2 pd setae apically; mid tibia with 1 ad, $2-4$ pd and $1 \mathrm{v}$ setae; hind tibia with $2-5$ ad, 3-4 pd, 3-5 $\mathrm{v}$ and $3 \mathrm{~d}$ preapical setae.

Abdomen. Yellow in ground color in most species (shining gray in glaucescens); syntergum $1+2$ not excavated to posterior margin, without median marginal seta, and with pair of lateral marginal setae or lacking; terga 3-4 with pair of median and lateral marginal setae in all species, without lateral discal setae in most species; tergum 5 with strong erect marginal setae, about 0.6 times as long as 4 th.

Male genitalia. Surstylus fused or not fused with epandrium at base, usually longer than cerci, varied in shape, narrow or broad, straight or curved dorsally, with some fine setae; cerci weakly or strongly curved dorsally in profile, with setae on basal half or $2 / 3$; ejaculatory apodeme usually fan-shaped; aedeagal apodeme extended ventrally beyond base of aedeagus, but not in luteola; paramere slightly or strongly bifurcated apically, upper lobe shorter than lower one; gonopod varied in shape, sclerotized in C-shaped and lateral edge projected outwardly, or with enlarged membranous area bearing spinules anteriorly, or sickle-like posteriorly; epiphallus present or absent; distiphallus highly varied, truncated apically or its dorsal and ventral portions pointed or broadened laterally, with posterolateral arm, bearing some small spinules ventrally.

Female terminalia. Short; terga 6-7 present as narrow, small hemitergites; sterna 6-7 oblong with strong setae, in silacea group with minute setulae, in some species anterior margin projected forward as invagination; sternum 8 fan-shaped, with strong setae; hypoproct present as median sclerite with strong setae; spiracle 6 present on or close to tergum 6 ; spiracle 7 in membrane anterior to or on tergum 7.

First instar larva. Labrum broad or sharp and narrow apically; lateral sclerite long and slender or triangular with slender anterior projection; hypopharyngeal region with distinct roof of food canal or not obvious; hypopharyngeal sclerite normal; dorsal cornu short and slender or long and somewhat broad; ventral cornu broad; each segment with tiny spinules or without; abdominal segment 7 with one to several rows of fine spinules or many rows of strong spinules ventrally; segment 8 with rows of spinules or some strong spinules ventrally.

\section{Key to Japanese species of Ceromya}

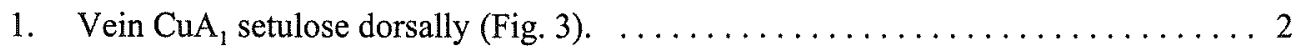

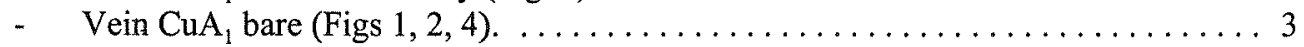

2. Thoracic dorsum yellow; anterior reclinate orbital seta long, about 2.5 times as long as posterior one, situated on anterior $1 / 3$ of fronto-orbital plate.

C. silacea (MEIGEN)

- Thoracic dorsum gray; anterior reclinate orbital seta short, about 2 times as long as posterior one, situated near middle of fronto-orbital plate. $\ldots \ldots \ldots \ldots \ldots \ldots \ldots$ C. dorsigera HerTING

3. Vein $\mathrm{R}_{1}$ setulose dorsally for entire length (Figs $1,2,3$ ) or on apical $1 / 2 \ldots \ldots 4$

- Vein $\mathrm{R}_{1}$ bare (Fig. 4 ) or with $2-3$ dorsal setae at apex. $\ldots \ldots \ldots \ldots \ldots$ 


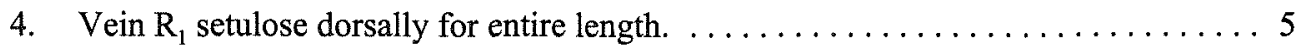

- Vein $R_{1}$ setulose dorsally on apical $1 / 2$.

C. prominula sp. $\mathrm{n}$.

5. Thoracic dorsum gray; gena wide, $0.21-0.27$ of eye-height.

C. pendleburyi (MALLOCH)

- Thoracic dorsum yellow; gena narrow, $0.14-0.17$ of eye-height. . .. C. helvola sp. n.

6. Vein $\mathrm{R}_{4+5}$ setulose dorsally nearly to level of crossvein $\mathrm{dm}$-cu or to beyond it; abdomen

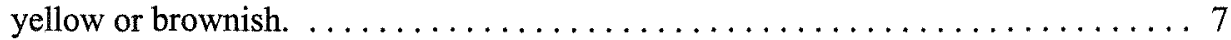

- Vein $\mathrm{R}_{4+5}$ setulose dorsally nearly to crossvein $\mathrm{r}-\mathrm{m}$; abdomen shining gray. .......... ..................................... . glaucescens sp. $\mathrm{n}$.

7. Thoracic dorsum yellow. $\ldots \ldots \ldots \ldots \ldots \ldots \ldots \ldots \ldots \ldots \ldots \ldots$

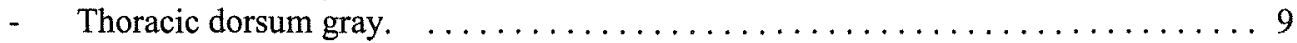

8. Vertex wide, about 0.4 of head width; tegula light yellow. ....... C. luteola sp. $\mathrm{n}$.

- Vertex narrow, about 0.35 of head width; tegula black. ....... C. kurahashii sp. n.

9. $3+4 \mathrm{dc}$; thoracic pleura gray. ................... C. pruinosa SHIMA

- $\quad 3+3 \mathrm{dc}$, thoracic pleura yellow. ................... Cothurnata sp. n.

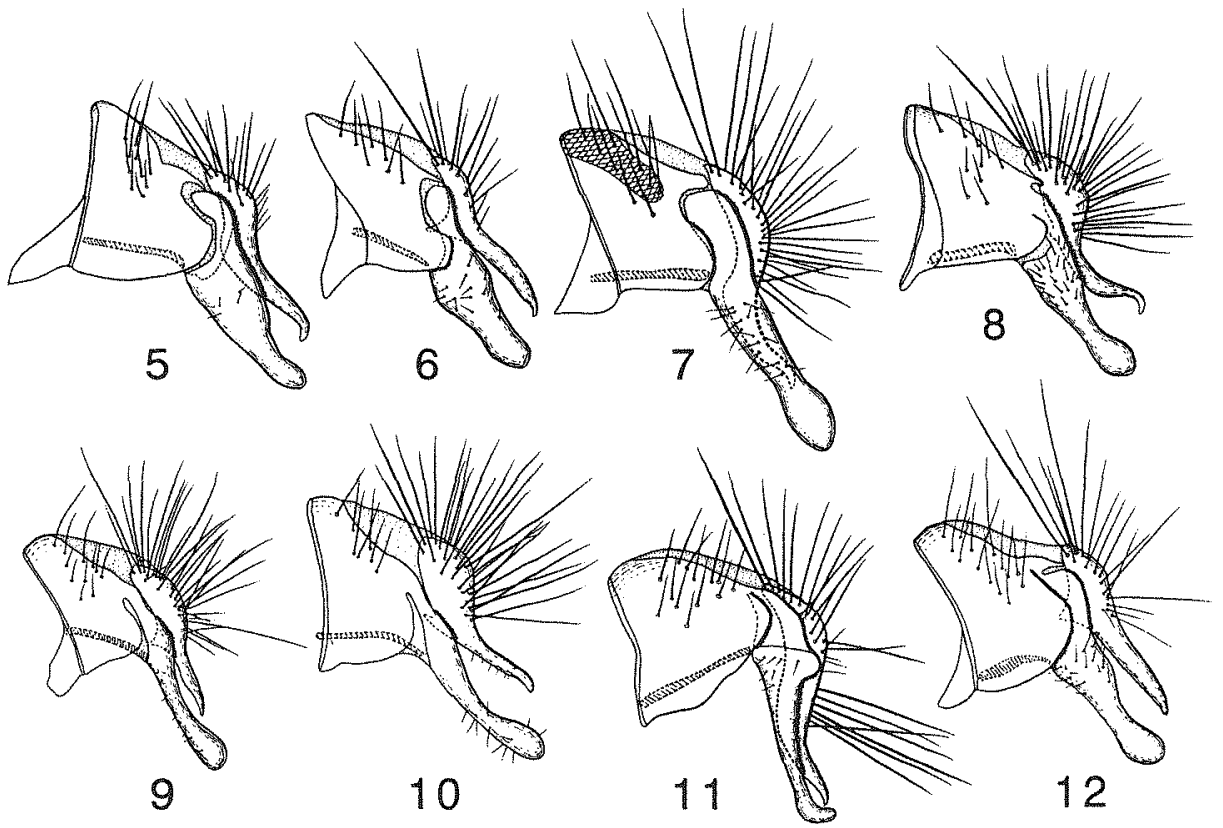

Figs 5-12. Epandria, surstyli, and cerci in lateral view. - 5. C. pruinosa; 6. C. prominula; 7. C. glaucescens; 8. C. kurahashii; 9. C. helvola; 10. C. pendleburyi; 11. C. cothurnata; 12. C. luteola.

\section{The bicolor group}

Diagnosis. Male genitalia: surstylus not fused with epandrium at base; gonopod with lateral edge projected outwardly; distiphallus truncated apically. First instar larva: labrum broad apically (Figs 54, 55). 
Remarks. This group was established by O'HARA (1994) based on the peculiar structure of the male genitalia: lateral edge of the sclerotized portion on the gonopod is extended downward (Fig. 51). O'HARA (1. c.) included C. bicolor, C. cephalotes, C. flaviceps, and C. pruinosa in this group and we add one species from Japan, $C$. prominula sp. n. to this group.

Ceromya bicolor, $C$. flaviceps, and $C$. pruinosa are very similar to each other in general features and male genital characters, with $C$. pruinosa appearing to be more closely related to $C$. bicolor than to $C$. flaviceps by the following characters: male genitalia with surstylus in lateral view broad at middle (Fig. 5); distiphallus truncated apically, with membrane on apical 1/5 (Fig. 21); sternum 5 without accessory lobes (Fig. 37). Ceromya prominula sp. n. distinctly differs from them by the presence of setulae on the apical $1 / 2$ of vein $R_{1}$ and the developed accessory lobes on the male sternum 5 (Fig. 38).

\section{Ceromya pruinosa SHIMA}

(Figs $5,13,21,29,37$ )

Ceromya pruinosa SHIMA, 1970: 188.

A detailed description of this species is given by SHIMA (1970).

Diagnosis. Thoracic dorsum dark gray, with whitish-yellow pollinosity; postpronotal lobe light gray, with whitish-yellow pollinosity; pleura gray, with whitish pollinosity. $3+4 \mathrm{dc} ; \mathrm{R}_{1}$ with 2 3 dorsal setae at apex; $\mathrm{R}_{4+5}$ setulose dorsally nearly to level of crossvein $\mathrm{dm}-\mathrm{cu} ; \mathrm{CuA}_{1}$ bare; abdomen brownish, with thin whitish-gray pollinosity; sternum 5 with pair of elongate median lobes, flattened on inner edge; accessory lobe absent. Male genitalia. Surstylus not fused with epandrium at base; surstylus broad at middle and slightly curved dorsally at apex in lateral view; cerci weakly curved dorsally, apex strongly curved ventrally in lateral view; paramere slightly bifurcated; gonopod sclerotized, C-shaped, with lateral edge projected outwardly, apex extended posteriorly and sharpened; epiphallus absent; distiphallus similar to $C$. prominula. Female. Unknown.

Body length. 4.5-5.0 $\mathrm{mm}$.

Specimens examined. Holotype male, Berabonai, Ashoro-cho, Hokkaido, 22.vii.1967; paratype, 1 male, Kiyokawa, Ashoro-cho, Hokkaido, 23.vii.1967 (BLKU). Additional materials examined. JAPAN [Hokkaido] 1 male, Tôro Lake, Shibecha-cho, 14.viii.1996 (BLKU); 1 male, Nukabira, Obihiro, 28.vi.1955 (SEHU).

Distribution. Japan (Hokkaido).

Host. Unknown.

Remarks. This species appears to be very closely related to $C$. bicolor and $C$. flaviceps, but is distinguished from them by the following characters: vein $R_{1}$ always with 2-3 dorsal setae at apex; abdomen brownish, with thin whitish gray pollinosity; male genitalia with surstylus broad at middle and slightly curved dorsally at apex.

\section{Ceromya prominula sp. $\mathbf{n}$.}

(Figs 6, 14, 22, 30, 38, 51)

Ceromya pruinosa: SHIMA, 1973: $155(\mathrm{nec})$.

Diagnosis. Thoracic dorsum dark gray with yellow pollinosity; $3+4 \mathrm{dc} ; \mathrm{R}_{1}$ setulose dorsally on apical $1 / 2$, bare ventrally; $R_{4+5}$ setulose dorsally nearly to level of crossvein dm-cu; $\mathrm{CuA}_{1}$ bare. Description. Male. Head. Vertex about 0.35 of head width; parafacial subequal in width to length of 2 nd aristomere at middle height; gena $0.24-0.3$ of eye-height; 5 frontal setae; anterior reclinate orbital seta slightly posterior to middle of fronto-orbital plate, about 1.5 times as long 
as posterior seta; antenna with 1st flagellomere subrectangular, about 1.7 times as long as wide and 3-3.3 times as long as pedicel; 2 nd aristomere about 2 times as long as wide; 3 rd aristomere thickened on basal half; prementum normal, about 4 times as long as wide.

Thorax. Dorsum dark gray, with yellow pollinosity; scutellum and pleura brownish- yellow; postpronotal lobe whitish yellow, with yellow pollinosity. $3+4 \mathrm{dc}$; subapical scutellar seta about 2 times as long as scutellum.

Wing. Hyaline; tegula black; basicosta light yellow. Relative lengths of costal sectors $2 \mathrm{nd}$, 3rd, and 4 th approximately as 2: 8: 3.5; costal seta short; ultimate section of $\mathrm{CuA}_{1}$ 0.4-0.48 times as long as penultimate section, and 1.3-1.6 times as long as crossvein dm-cu; $R_{1}$ setulose dorsally on apical $1 / 2$, bare ventrally; $R_{4+5}$ setulose dorsally nearly to level of crossvein dm-cu; $\mathrm{CuA}$, bare.

Legs. Fore tibia without pd seta; mid femur with 1 preapical ad setae.

Abdomen. Yellow in ground color, without pollinosity; syntergum $1+2$ to terga 5 with black mid-dorsal longitudinal vitta; apical $1 / 4$ of terga 4-5 with black transverse band. Syntergum $1+2$ without lateral marginal seta; terga 3-4 without lateral discal seta; sternum 5 with pair of elongate median lobes, flattened on inner edge; pair of accessory lobes strongly developed on inner edge.

Male genitalia. Surstylus not fused with epandrium at base, in lateral view nearly straight, slightly broaded and with some setae at middle; cerci in lateral view nearly straight, narrow on apical half; paramere slightly bifurcated at apex; gonopod with lateral edge projected outside, apex strongly curved inwardly and sharpened; epiphallus absent; distiphallus in lateral view truncated apically, bearing some small spinules ventrally, membranous on apical 1/5.

Female. Similar to male, but differing as follows: antenna with 1st flagellomere slender, about 2 times as long as wide and 3 times as long as pedicel.

Body length. 4.5-5.0 mm.

Holotype male, Yamaguchi, Tokorozawa city, Saitama, Honshu, Japan, 13.vii.1986 emerged, N. Ishizawa (BLKU).

Paratypes. JAPAN [Honshu] 2 males, same data as holotype; 1 female, Mt. Nagamine, T. Tsukiyama, 2.vii.1970 col., (15.vii.1970 emerged) (all in BLKU).

Etymology. This species is named for the projected accessory lobe on the male sternum 5.

Distribution. Japan (Honshu).

Host. LEPIDOPTERA: Lasiocampidae, Cyclophragma undans (Walker) [Yamaguchi, Tokorozawa city, Saitama].

Remarks. This species distinctly differs from other members of this group by the following characters: $R_{1}$ setulose dorsally on apical 1/2; sternum 5 with pair of developed accessory lobes on inner edge; male genitalia with surstylus nearly straight, a little thickened at middle in lateral view; cerci nearly straight, narrow on apical half in lateral view; gonopod with lateral edge projected outwardly, apex strongly curved inside and sharpened.

All specimens examined were obtained by rearing from hosts. This species was recorded by SHIMA (1973) as C. pruinosa, but we recognize it to be new species here.

\section{The flaviseta group}

Diagnosis. Male genitalia: surstylus fused or not fused with epandrium at base; gonopod with enlarged membranous area bearing spinules anteriorly; epiphallus present or absent; distiphallus in lateral view almost sclerotized, bearing small spinules ventrally, and lateral portion largely membranous. First instar larva: labrum broad apically (Figs 56, 57). 


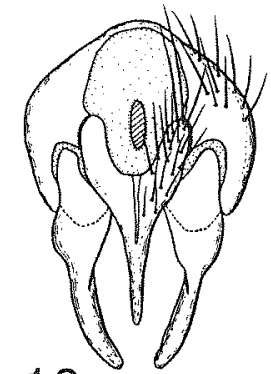

13

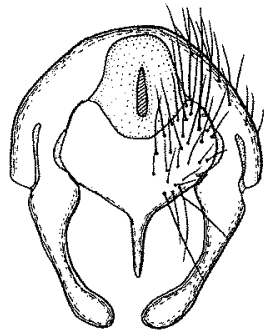

17

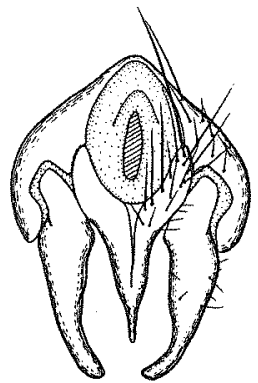

14

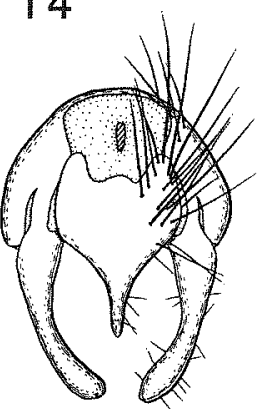

18
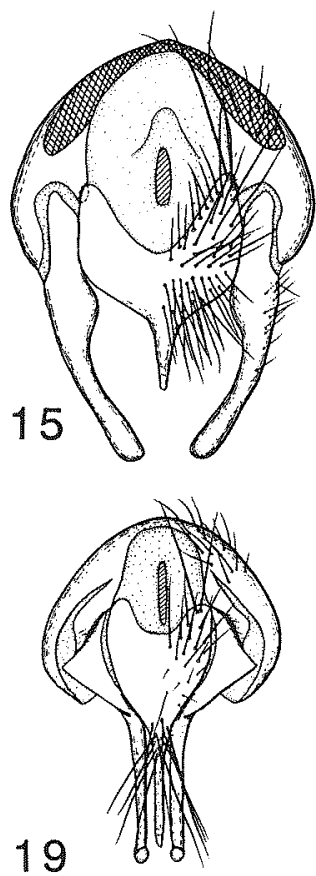
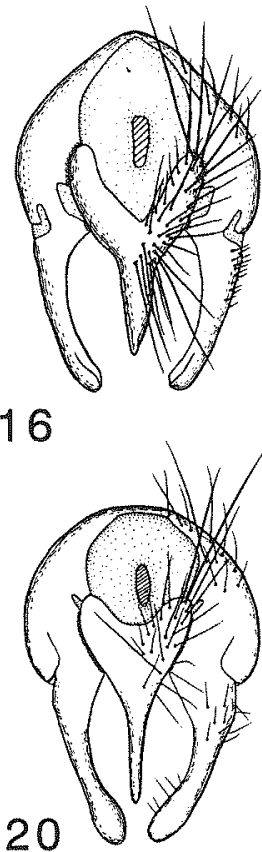

Figs 13-20. Epandria, surstyli, and cerci in dorsal view (setae omitted on left side). - 13. C. pruinosa; 14. C. prominula; 15. C. glaucescens; 16. C. kurahashii; 17. C. helvola; 18. C. pendleburyi; 19. C. cothurnata; 20. C. luteola.

Remarks. The flaviseta group is characterized in having the following features: male genitalia with surstylus elongate and slender basally (Figs 8,16 ); dorsal and ventral portions of distiphallus pointed (Figs 23, 24). O'Hara (1994) included C. flaviseta, C. ontario, C. palloris, and tentatively $C$. dilecta in this group.

Ceromya glaucescens and C. kurahashii are very similar to members of the flaviseta group (we have examined C. ontario, C. palloris, and C. flaviseta) in the structure of the distiphallus and gonopod, and they are included in this group. However, in C. flaviseta and C. glaucescens the surstylus is not fused with epandrium basally (Figs 7, 15).

The autapomorphy of this group is recognized only in the feature of the distiphallus: dorsal and ventral portions of distiphallus pointed (O'HARA, 1994). Monophyly of this group remains weak because the shap of the distiphallus described above is observed in some undescribed species from New Guinea that do not appear to belong to this group. This group is known only from a few Palearctic and Nearctic species so far. However, there are still numerous undescribed species that appear to belong to this species group in Asia and the Oriental Region. Phylogenetic relationships and autapomorphies of this group may become clearer when species from these regions are studied in detail.

\section{Ceromya glaucescens sp. $\mathbf{n}$.}

(Figs $7,15,23,31,39,52$ )

Diagnosis. Thoracic dorsum and pleura dark gray, with yellow pollinosity; $3+4 \mathrm{dc} ; \mathrm{R}_{1}$ bare; $R_{4+5}$ setulose dorsally nearly to crossvein $\mathrm{r}-\mathrm{m}$ (sometimes beyond it with a few setae); $\mathrm{CuA}$ bare. 
Description. Male. Head. Fronto-orbital plate dark gray; frontal vitta orange to reddishbrown; gena orange at genal groove; postgena and occiput gray; antenna with pedicel and scape orange; 1st flagellomere reddish brown to black; arista dark brown; palpus orange. Vertex 0.38 -0.42 of head width; parafacial narrower than length to 2 nd aristomere at middle height; gena 0.21-0.28 of eye-height; 5 frontal setae; anterior reclinate orbital seta situated posterior to middle of fronto-orbital plate, about 2.5 times as long as posterior seta; upper occiput and postgena with only black setae; antenna with 1st flagellomere 1.57-1.87 times as long as wide and 4.3-6 times as long as pedicel; 2 nd aristomere variable, 3-4 times as long as wide and 2.6-5 times as long as 3rd; 3rd aristomere thickened on basal 1/2-3/5; prementum normal, 3-4 times as long as wide.

Thorax. Dorsum and pleura dark gray, with yellow pollinosity. $3+4 \mathrm{dc}$; lower katepisternal seta subequal in length to anterior seta; subapical scutellar seta about 2.6 times as long as scutellum.

Wing. Hyaline; tegula reddish brown; basicosta orange. Relative lengths of costal sectors $2 \mathrm{nd}$, 3rd, and 4th approximately as 2: 8: 3; costal seta not distinguishable from the other setae; ultimate section of $\mathrm{CuA}_{1}$ 0.25-0.3 times as long as penultimate section, and subequal in length to crossvein dm-cu; $R_{1}$ bare; $R_{4+5}$ setulose dorsally nearly to crossvein $r-m$ (sometimes beyond a few setae); $\mathrm{CuA}$ bare.

Legs. Orange in ground color. Outer surface of fore femur dark gray, inner surface on apical $1 / 4$ and basal $1 / 4$ orange; coxa gray. Fore tibia with 4 ad setae, without pd and p setae; mid tibia with 2 pd setae; hind tibia with 4-6 ad and 3-4 pd setae of unequal lengths, and $4 \mathrm{v}$ setae. Abdomen. Shining gray in ground color; anterior $1 / 2$ of terga 3-4 and anterior $2 / 3$ of tergum 5 with bluish-white pollinosity. Syntergum $1+2$ with pair of lateral marginal setae; terga $3-4$ with pair of lateral discal setae; sternum 5 with pair of elongate median lobes, flattened on inner edge; pair of accessory lobes slightly developed on inner edge.

Male genitalia. Epandrium with dark brown area at upper part; surstylus not fused with epandrium at base, in lateral view nearly straight with setae at middle, slightly broadened apically; cerci in lateral view curved dorsally with many setae on basal $2 / 3$, much shorter than surstylus; paramere not bifurcated; gonopod with enlarged membranous area bearing spinules anteriorly; epiphallus absent; distiphallus in lateral view almost sclerotized, bearing small spinules ventrally, and lateral portion largely membranous.

Female. Unknown.

Body length. 4.5-5.0 mm.

Holotype male, Sasagamine, Myôkôkôgen-cho, Niigata, Honshu, Japan, 23.vi.1996, T. Tachi (BLKU).

Paratypes. JAPAN [Honshu] 1 male, Asamushi, Aomori city, Aomori, 25.iv.1982, S. Fukushi; 1 male, Shimashima-dani, Azumi village, Nagano, 22.v.1975 (malaise trap), A. Nakanishi \& J. Emoto. [Shikoku] 1 male, Mt. Tsurugi, Minokoshi, Tokushima, 29.iv.1998, T. Tachi. [Kyushu] 1 male, Kashiwaga, Tomochi-machi, Kumamoto, 4.v.1981, I. Ohtsuka; 1 male, Mt. Shiratori, Kumamoto, 18.iv.1981, I. Otsuka (all in BLKU).

Etymology. This species is named for the gray body.

Distribution. Japan (Honshu, Shikoku, Kyushu).

Host. Unknown.

Remarks. This species is distinct from the other Japanese species of Ceromya in having a dark gray body color and orange legs. The gonopod and distiphallus of this species are very similar to other members of this group, but the cerci and surstylus distinctly differ from those of the latter: cerci in lateral view weakly curved dorsally at middle; surstylus in lateral view nearly straight, not fused with the epandrium at base.

Adults of this species appear in early spring. 


\section{Ceromya kurahashii sp. $\mathrm{n}$.}

(Figs 8, 16, 24, 32, 40, 45)

Diagnosis. Thoracic dorsum yellow, with golden pollinosity; tegula black; vertex about 0.35 of head width; $3+4 \mathrm{dc} ; \mathrm{R}_{1}$ bare; $\mathrm{R}_{4+5}$ setulose dorsally slightly to beyond level of crossvein $\mathrm{dm}$ $\mathrm{cu} ; \mathrm{CuA}_{1}$ bare.

Very similar to $C$. luteola, but differing as follows.

Description. Male. Head. Whitish-yellow in ground color; ocellar triangle yellow. Vertex narrow, about 0.35 of head width; gena about 0.33 of eye-height; fronto-orbital plate with some fine setae; antenna with 1st flagellomere suboval, about 1.8 times as long as wide and 2.6-3.3 times as long as pedicel.

Thorax. Dorsum yellow, with golden pollinosity. $3+4 \mathrm{dc}$.

Wing. Tegula black; basicosta light yellow. $\mathrm{R}_{1}$ bare; $\mathrm{R}_{4+5}$ setulose dorsally slightly to beyond level of crossvein dm-cu; $\mathrm{CuA}_{1}$ bare.

Abdomen. Syntergum 1+2 usually without lateral marginal seta; terga 3-4 with pair of lateral discal setae; sternum 5 with pair of elongate median lobes, flattened on inner edge; accessory lobe absent.

Male genitalia. Surstylus fused with epandrium at base, with short setae at middle; cerci in lateral view strongly curved dorsally at middle, with many long setae on basal half; gonopod with membranous area bearing spines; epiphallus present; distiphallus in lateral view almost sclerotized, bearing small spinules ventrally, and lateral portion largely membranous.

Female. Similar to male, differing as follows: antenna with 1st flagellomere slender, about 2 times as long as wide and 3.5 times as long as pedicel.

Female terminalia. Sternum 5 nearly rectangular; tergum 6 elongate, shorter than sternum 5; sternum 6 nearly oblong; tergum 7 much shorter than tergum 6 ; sternum 7 oblong, without anterior apodeme; spiracle 6 present on tergum 6; spiracle 7 in membrane anterior to tergum 7 . Body length. 5.2-5.5 mm.

Holotype male, Mt. Asamayama, Nagano, Honshu, Japan, 11.viii.1976, H. Kurahashi (BLKU).

Paratypes. JAPAN. [Honshu] 1 male, Renge spa, Itoigawa city, Niigata, 27.vii.1998 (malaise trap), T. Tachi; 1 female, same data as holotype (all in BLKU).

Etymology. This species is named in honor of Dr. H. Kurahashi (Department of Medical Entomology, The National Institute of Health), who collected the type specimens.

Distribution. Japan (Honshu).

Host. Unknown.

Remarks. This species is very similar to $C$. luteola, but distinguished from it by male genital characters: accessory lobes absent; cerci in lateral view strongly curved dorsally, with many long setae on basal half. Other differences between these species are stated in Remarks under C. luteola.

\section{The silacea group}

Diagnosis. Male. Inner edge of sternum 5 even and unmodified; surstylus fused with epandrium at base; paramere bifurcated apically, short upper and long lower lobes; gonopod in lateral view sickle-like posteriorly; epiphallus absent; distiphallus in lateral view broad, with posterolateral arm, and deeply bifurcated at apex in dorsal view. Female terminalia: abdominal sterna 6-7 with minute setulae. First instar larva: labrum sharp and narrow apically (Figs 59, 61 ); dorsal cornu short and slender; abdominal segment 7 with many rows of distinct spinules ventrally (Figs 58,60). 


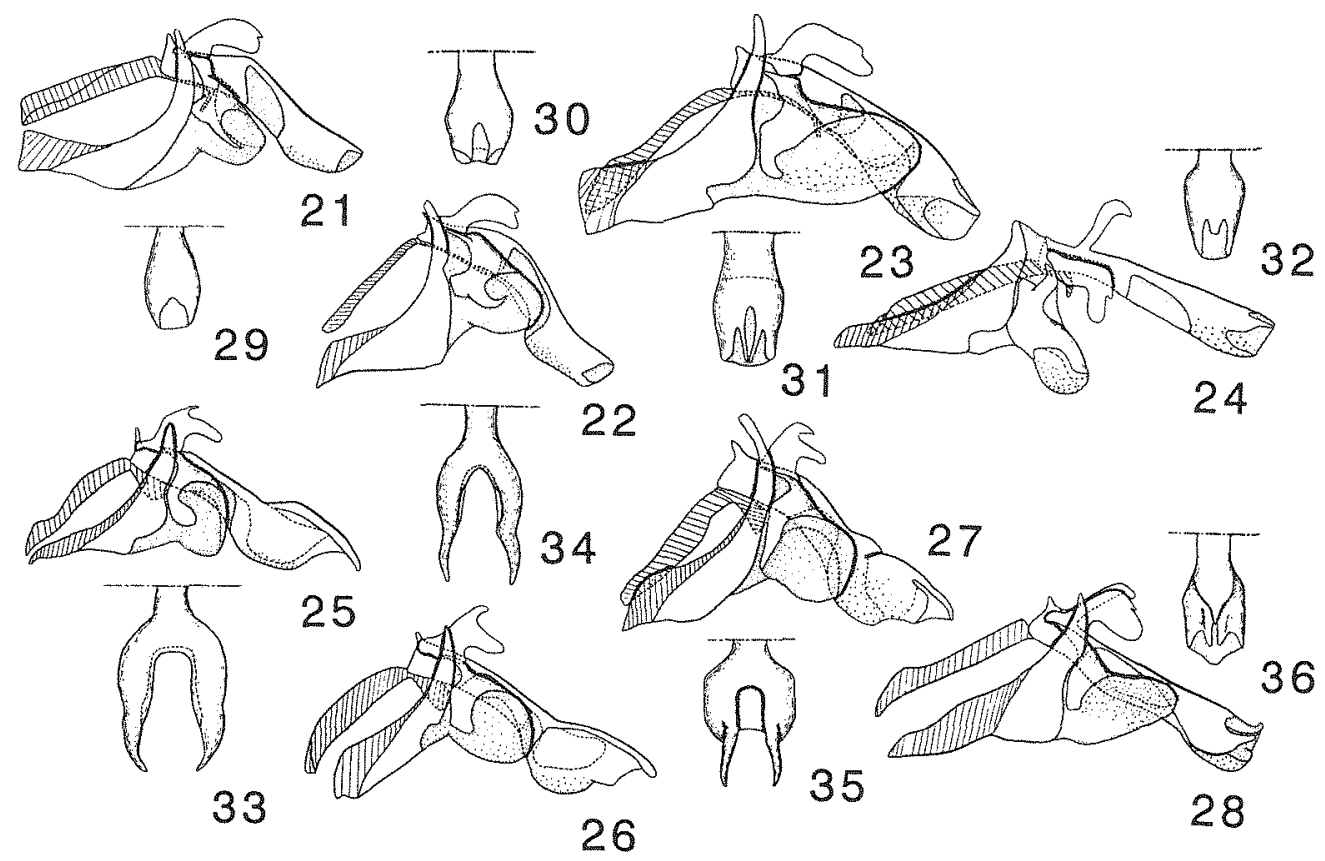

Figs 21-28. Hypandria, gonopods, parameres, and distiphalli in lateral view. - Figs 29-36. Distiphalli in dorsal view. $-21,29$. C. pruinosa; 22, 30. C. prominula; 23, 31. C. glaucescens; 24, 32. C. kurahashii; 25, 33. C. helvola; 26, 34. C. pendleburyi; 27, 35. C. cothurnata; 28,36 . C. luteola.

Remarks. O'HARA $(1988,1989)$ considered autapomorphies of this group as follows: male genitalia with distiphallus uniquely infolded and sclerotized structure formed from posterior surface which is deeply U-shaped in posterior view (Figs 33,34); possibly hook-like labrum of 1st instar larva (Figs 59-62). We consider that the following character also should be added to the autapomorphies of this group: female abdominal sterna 6-7 with numerous minute setulae (Fig. 46).

This group is exclusively distributed in the Old World, and includes the following species (O’Hara 1989): C. dorsigera Herting, C. mellina (Mesnil), C. normula (Curran), C. patellicornis Mesnil, C. pendleburyi (Malloch), C. silacea (Meigen), C. similata Mesnil, and C. varichaeta (Curran). In the present study, we add one new species, $C$. helvola sp. n. to this group. In our present examination, Ceromya patellicornis and four Japanese species, $C$. dorsigera, $C$. helvola, C. pendleburyi, and C. silacera appear to be closely related to each other and by external features and male genital characters. C. dorsigera and C. patellicornis may be more closely related to each other than other members of this group by the following apomorphic characters: the strongly curved cerci; the presence of setulae on the surstylus.

\section{Ceromya dorsigera HeRTING}

(Figs 46, 60, 61)

Ceromya dorsigera HERTING, 1967: 8.

Description and figures of this species are given by ANDERSEN (1996), HERTING (1967) and SHIMA (1970). 
Diagnosis. Thoracic dorsum dark gray; postpronotal lobe and pleura whitish-yellow. Anterior reclinate orbital seta short, about 2 times as long as posterior seta and situated near middle of fronto-orbital plate; $3+3 \mathrm{dc} ; \mathrm{R}_{1}$ setulose dorsally on entire length, on apical $1 / 3$ ventrally; $R_{4+5}$ setulose dorsally nearly to wing margin; $\mathrm{CuA}_{1}$ setulose dorsally to crossvein $\mathrm{dm}$-cu. Male genitalia similar to $C$. silacea, but differing as follows: cerci in lateral view sharply curved dorsally at middle, apex strongly curved ventrally; surstylus with setae on entire length. Female terminalia. Similar to $C$. helvola, but differing as follows: sternum 8 in lateral view pointed posteriorly. First instar larva. Similar to C. silacea.

Body length. 4.5-5.3 mm.

Additonal material. JAPAN [Hokkaido] 1 female, Sapporo, 25.vi.1958 (SEHU); 1 male, Rubesu, Nemuro, 25-28.viii.1971. [Honshu] 1 male, Yagen, Shimokita, Aomori, 9.viii.1971; 1 female, Orikabe, Oohasama-cho, Iwate, 9.viii.1996; 1 female, Rokujuurigoe, Asahi village, Yamagata, 12.viii. 1996; 1 male, Moroyama, Iruma, Saitama, 26.viii. 1986; 1 male, Yorii, Saitama, 29.iv.1972; 1 female, Minono, Saitama, 8.x.1973; 1 female, same locality, 30.x.1974; 1 female, same locality, 25.x.1977; 1 female, Yunosawa-tôge, Yamato village, Yamanashi, 17. vii.1996; 1 female, Kozagawa, Wakayama, 14-20.v.1964 (SEHU). [Kyushu] 1 male, Aburayama, Fukuoka city, Fukuoka, 19.vii.1991; 1 female, Sefuriyama, Fukuoka city, Fukuoka, 1.x.1996; 1 female, Mt. Kurinodake, Kurino-cho, Kagoshima, 18.vii.1997. RUSSIA [Ussuria: Primorsk Terr.] 1 female, Ussuriysk Reserve (150m), 22-26.vii.1990 (malaise trap). TAIWAN. 1 male, Yehliu beach, Wanli-hsiang, Taipei-hs., 27.xi.1997; 1 male, Suchilanchi $(1600 \mathrm{~m})$, Huanchan, Taichung-hs., 24.xi.1997; 1 male, Hungshuichi (500m), Liukuei-hsiang, 22.xi.1997 (malaise trap) (all in BLKU except as indicated).

Distribution. Japan (Hokkaido, Honshu, Kyushu*); Taiwan*, S. Germany, Hungary, Switzerland, Austria, N. Spain and Russia.

Host. Unknown in Japan.

Remarks. This species is similar to C. silacea, but distinguished from it by the following characters: surstylus with fine setae; apex of cerci sharply curved ventrally; distiphallus in lateral view broadly sclerotized. Other differences between these species are stated in Remarks under C. silacea.

\section{Ceromya helvola sp. $\mathbf{n}$.}

(Figs 1, 9, 17, 25, 33, 41, 47)

Diagnosis. Thoracic dorsum and scutellum yellow; postpronotal lobe and pleura light yellow; $3+3 \mathrm{dc} ; R_{1}$ setulose dorsally on entire length, on apical $1 / 3$ ventrally; $R_{4+5}$ setulose dorsally nearly to wing margin; $\mathrm{CuA}_{1}$ bare.

Very similar to $C$. pendleburyi, but differing as follows.

Description. Male. Head. Almost light yellow in ground color, with whitish pollinosity; frontal vitta light yellow to yellow; antenna with 1st flagellomere yellowish-brown to testaceous. Parafacial much narrower than length of 2 nd aristomere at middle height; gena 0.140.18 of eye-height; $3-4$ frontal setae (if 4 setae, then 3 rd seta very fine); antenna with 1st flagellomere oval, 1.7-1.9 times as long as wide and 3.3-4.1 times as long as pedicel.

Thorax. Dorsum yellow, with whitish-yellow pollinosity; postpronotal lobe and pleura light yellow, with whitish-yellow pollinosity. Usually $3+3 \mathrm{dc}$ (if $3+4 \mathrm{dc}$, then 2 nd postsutural seta very short).

Wing. Ultimate section of $\mathrm{CuA}_{1}$ 0.26-0.32 times as long as penultimate section, and subequal in length to crossvein dm-cu; $R_{1}$ setulose dorsally on entire length, on apical $1 / 3$ ventrally; $R_{4+5}$ setulose dorsally nearly to wing margin; $\mathrm{CuA}_{1}$ bare. 
Legs. Mid femur with 1 preapical ad seta; mid tibia with 3-4 pd setae.

Abdomen. Yellow in ground color, almost without pollinosity. Tergum 4 with pair of lateral black spots (sometimes black band) on apical 1/3; tergum 5 with black band on apical 1/2. Syntergum 1+2 without lateral marginal seta; terga 3-4 with pair of lateral discal setae.

Male genitalia. Surstylus fused with epandrium at base, in lateral view slender and slightly curved dorsally at middle; cerci in lateral view nearly straight, narrow on apical half; epiphallus absent; distiphallus in lateral view broadly sclerotized, with small spines ventrally.

Female. Similar to male, but differing as follows: gena narrower, 0.12-0.16 of eye-height; antenna with 1st flagellomere slender, 2.5-3 times as long as wide.

Female terminalia. Sternum 7 without anterior apodeme.

First instar larva. Similar to C. silacea.

Body length. 4.5-5.0 mm.

Holotype male, Yubaridate, Sorachi, Hokkaido, Japan, 15.vii.1969, T. Saigusa (BLKU).

Paratypes. JAPAN [Hokkaido] 1 female, Mt. Rausu (200-900m), 3.viii.1967, H. Shima; 1 male, 1 female, Penkenûshi, Hidaka-cho, 24.vi.1997, R. Matsumoto; 3 females, Berabonai, Ashoro-cho, 22, 24.vii.1967, M. Honda and A. Nakanishi. [Honshu] 1 female, Ishinoto, Owani-cho, Aomori, 2.viii.1983, S. Fukushi; 1 female, Tsurunoyu, Tazawako-cho, Akita, 10.viii.1996, M. Sueyoshi; 1 male, 1 female, Renge spa, Itoigawa city, Niigata, 16.viii.1997 (malaise trap), 27.vii.1998, T. Tachi; 1 male, Kobotoke-tôge, Hachiôji city, Tôkyô, 22.vi.1997, R. Matsumoto; 1 male, Mt. Kumakura, Chichibu Mts., Saitama, 27.viii.1986, T. Hayashi; 1 female, Yasyagami, Ashiyasu village, Yamanashi, 28.viii.1996 (at light), M. Sueyoshi. [Kyushu] 2 males, 4 females, Shiibagoe, Izumi village, Kumamoto, 25.vii.1997, T. Tachi; 1 male, same locality, 5.viii.1998, M. Sueyoshi. KOREA. 1 female, Mt. Sudo-san (1000m), Gyongsangbug-do, 1.viii.1977, K. Yamagishi. RUSSIA [Ussuria: Primorsk Terr.] 2 males, Ussuriysk Reserve Camp (140-160m), 21.vii.1990, T. Saigusa; 1 male, same locality, 22-26. vii. 1990, T. Saigusa. (all in BLKU).

Etymology. This species is named for the yellow body.

Distribution. Japan (Hokkaido, Honshu, Kyushu); Korea; Russia.

Host. Unknown.

Remarks. This species is very similar to $C$. pendleburyi, but differs from it in having a yellow thoracic dorsum and narrow gena.

\section{Ceromya pendleburyi (MALLOCH)}

(Figs 2, 10, 18, 26, 34, 42, 48, 53)

Actia pendleburyi MALLOCH, 1930: 144.

Diagnosis. Thoracic dorsum dark gray; postpronotal lobe and pleura light yellow. $3+4 \mathrm{dc} ; \mathrm{R}_{1}$ setulose dorsally on entire length, on apical $1 / 3$ ventrally; $R_{4+5}$ setulose dorsally nearly to wing margin; $\mathrm{CuA}_{1}$ bare.

Redescription. Male. Head. Light yellow in ground color, with white pollinosity; frontoorbital plate light yellow to light gray, with whitish pollinosity; ocellar triangle black; frontal vitta light yellow to orange; antenna with scape, pedicel and basal $1 / 3$ of 1 st flagellomere yellow, brownish yellow on apical $2 / 3 ; 2$ nd and half of $3 \mathrm{rd}$ aristomere light yellow, black on apical 1/2; palpus whitish-yellow. Vertex about 0.34 of head width; parafacial much narrower than length of 2 nd aristomere at middle height (sometimes subequal in width to 2 nd aristomere); gena $0.21-0.26$ of eye-height; 3 frontal setae (if 4 frontal setae, then 3 rd seta very fine); anterior reclinate orbital seta situated near middle of fronto-orbital plate, thick and about twice 
as long as posterior seta; antenna with 1st flagellomere oval, about 1.6 times as long as wide and 4.2-5.4 times as long as pedicel; 2 nd aristomere 2-3 times as long as wide; 3 rd aristomere thickened on basal 3/8; prementum short, 3-3.5 times as long as wide.

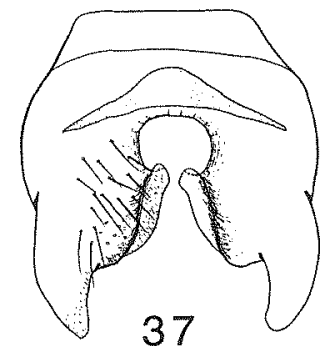

37

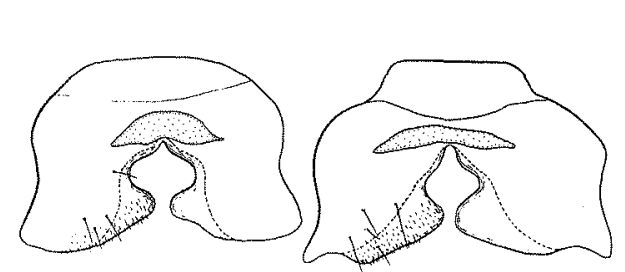

41

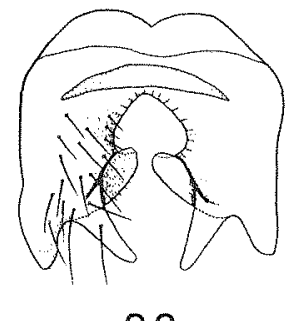

38

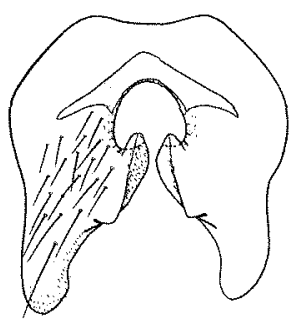

39

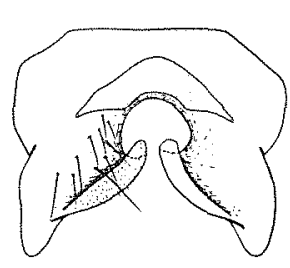

40

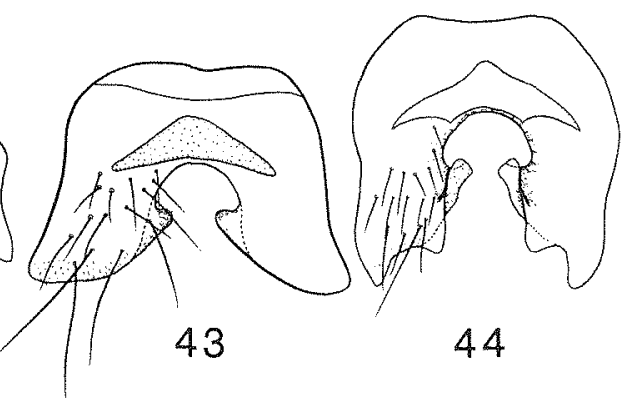

Figs 37-44. Male sterna 5 in ventral view (setae omitted on right side). - 37. C. pruinosa; 38. C. prominula; 39. C. glaucescens; 40. C. kurahashii; 41. C. helvola; 42. C. pendleburyi; 43. C. cothurnata; 44. C. luteola.

Thorax. Dorsum dark gray, with yellow pollinosity; postpronotum and pleura light yellow; scutellum yellow. Usually $3+4 \mathrm{dc}$ (sometimes $3+3 \mathrm{dc}$ ); subapical scutellar seta about twice as long as scutellum.

Wing. Hyaline; tegula black; basicosta light yellow. Relative lengths of costal sectors $2 \mathrm{nd}$, 3rd, and 4 th approximately as $2: 7: 3$; ultimate section of $\mathrm{CuA}_{1}$ about 0.3 times as long as penultimate section, and subequal in length to crossvein dm-cu; $\mathrm{R}_{1}$ setulose dorsally on entire length, on apical $1 / 3$ ventrally; $R_{4+5}$ setulose dorsally nearly to wing margin; $\mathrm{Cu} \mathrm{A}_{1}$ bare.

Legs. Fore tibia with 3-4 ad, 3 pd and 1 p setae; mid femur with 2 ad setae at middle and 2 pd setae apically; mid tibia with 1 ad, 2 pd and $1 \mathrm{v}$ setae; hind tibia with $2-4$ ad, $3-4$ pd and $3-4 \mathrm{v}$ setae.

Abdomen. Yellow in ground color, almost without pollinosity; terga 3-5 with pair of lateral black spots on apical $1 / 3$. Syntergum $1+2$ without lateral marginal seta; tergum 4 with pair of lateral discal setae in some specimens; sternum 5 even, without distinct median lobe on inner edge.

Male genitalia. Surstylus fused with epandrium at base, in lateral view slender, apex slightly curved dorsally; cerci in lateral view curved dorsally at middle, narrow on apical half; paramere bifurcated apically, short upper and long lower lobes; gonopod in lateral view sickle-like posteriorly; epiphallus absent; distiphallus in lateral view almost sclerotized, with spinules ventrally.

Female. Differing from male as follows: gena slightly narrower, about 0.2 of eye-height; antenna with 1st flagellomere slender, 2-2.2 times as long as wide. 


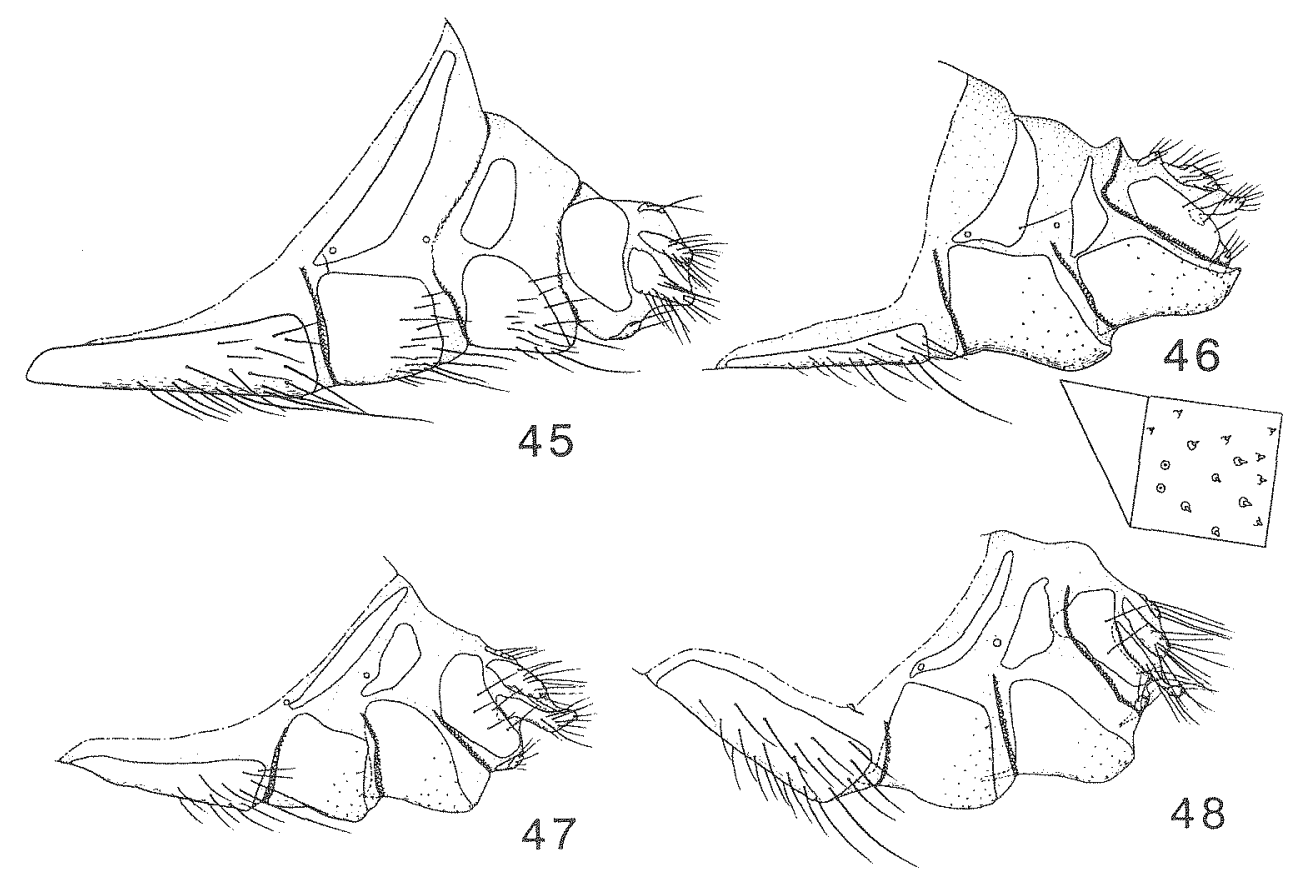

Figs 45-48. Female terminalia in lateral view. -45. C. kurahashii; 46. C. dorsigera; 47. . . helvola; 48. C. pendleburyi.

Female terminalia. Sternum 5 nearly oblong; tergum 6 elongate, shorter than sternum 5 ; sternum 6 nearly oblong, with minute setulae; tergum 7 shorter than tergum 6 ; sternum 7 oblong, with weakly sclerotized anterior apodeme and minute setulae; sternum 8 fan-shaped, with strong setae; spiracle 6 present on tergum 6 ; spiracle 7 in membrane anterior to tergum 7.

First instar larva. Similar to C. silacea.

Body length. 4.5-5.0 mm.

Specimens examimed. JAPAN [Honshu] 1 male, Inagawa, Okuwa village, Nagano, 3.vii. 1996; 1 female, Hontani river, Sudama-cho, Yamanashi, 1.ix.1975 (malaise trap); 1 female, Kanayama, Sudama-cho, Yamanashi, 26.vii.1975; 1 male, Yasyagami, Ashiyasu village, Yamanashi, 28.viii.1996 (at light); 1 male, Yunosawa pass, Yamato village, Yamanashi, 17.vii. 1996; 1 male, Mt. Wasamata, Kamikitayama, Nara, 27.vii.1995. [Shikoku] 1 male, Tsuchigoya, Omogo, Ehime, 9.viii.1998. [Kyushu] 1male, Momiki, Kumamoto, 4.viii.1998; 1 female, Naidaijin, Yabe village, Kumamoto, 25.v.1997; 1 male, Mt. Kurodake, Shônai-cho, Oita, 18.v. 1997; TAIWAN [Kaohsung] 1 male, Hungshuichi (500m), Liukuei-hsiang, 22.xi.1997 (malaise trap) (all in BLKU).

Distribution. Japan (Honshu, Shikoku*, Kyushu*); Taiwan*; Malaysia.

Host. Unknown in Japan.

Remarks. This species is similar to C. helvola, but can be distinguished from it by the following genital characters: male cerci in lateral view curved dorsally at middle; female terminalia with stemum 7 having elongated anterior apodeme.

Other differences between these species are stated in Remarks under C. helvola. 


\section{Ceromya silacea (MEIGEN)}

(Figs 3, 49, 58, 59)

Tachina silacea MEIGEN, 1824: 355.

See ANDERSEN (1996) for complete list of synonymies.

Redescription and figures of this species are given by ANDERSEN (1996), MESNIL (1963) and SHIMA (1970).

Diagnosis. Thoracic dorsum yellow; postpronotal lobe and pleura whitish-yellow. Anterior reclinate orbital seta long, 2-2.5 times as long as posterior seta and situated anterior $1 / 3$ of fronto-orbital plate: $3+3 \mathrm{dc} ; R_{1}$ setulose dorsally on entire length, on apical $1 / 3$ ventrally; $R_{4+5}$ setulose dorsally nearly to wing margin; $\mathrm{CuA}_{1}$ setulose dorsally to crossvein dm-cu. Male genitalia and female terminalia. Similar to $C$. pendleburyi, but differing as follows: spiracle 7 present on tergum 7. First instar larva. Refer to O'Hara (1988).

Body length. 5.0-5.5 mm.

Specimens examined. JAPAN [Hokkaido] 1 male, 1 female, Shimonaefutoro, Wakkani city, 21.viii.1997; 8 males, 3 females, Mt. Rausu-dake, Rausu-cho, 27, 28.vi.1997; 1 female, Okepepu-rindô, Shiretoko pen., 13.viii.1996; 2 males, 8 females, Gojikkoku, Shibecha-cho, 14, 15.viii.1996, 3.viii.1997; 18 males, 4 female, Tôro Lake, Shibecha-cho, 14.viii.1996, 31.vi., 1,3.viii.1997; 8 males, 16 females, Oketo-rindô, Kamishihoro-cho, 26.vi., 4.viii.1997; 1 male, 5 females, Mitsumata, Kamishihoro-cho, 6.viii.1997; 4 males, 10 females, Kamitoshibetsu, Ashoro-cho, 10-11, 16-17.viii.1996; 2 males, 5 females, Meakan, Ashoro-cho, 29, 31.vi.1997; 2 females, Onnetoh Lake, 10, 15.ix. 1997; 1 female, Shumarinai, Horokanai-cho, 22.viii.1997; 14 males, 1 female, Aizankei (550-800m), Mts. Daisetsu, 18-20.vii.1986; 1 female, Mt. Tomuraushi, 1.viii.1966; 1 male, Shiretoko-tôge, $600 \mathrm{~m}$, 30.viii.1995; 1 male, 1 female, Rubetsu, Nemuro, 25-28.viii.1971; 1 male, Mt. Yûbari, Sorachi, 15.vii.1967; 1 male, 1 female, Penkenûshi, Hidaka-cho, 24.vi.1997. [Honshu] 1 male, Yatate-Tôge, Aomori, 19.viii.1977; 2 females, Mannyokaisawa, Kawai village, Iwate, 9.viii.1996, 13.viii.1997; 1 male, Orikabe, Ohhasamam cho, Iwate, 9.viii.1996; 1 male, Mt. Iide, Fukushima, 27.vii.1970; 1 female, Kôtoku, Tochigi, 13.vi.1974; 1 male, 2 females, Sannô pass, Tochigi, 9.viii.1997; 1 male, Mt. Hachimori, Asahi village, Nagano, 16.vi.1997; 1 male, Karuizawa, Kutsukake, Nagano, 10. vii.1966; 1 male, Sawara-ike, Nirasaki city, Yamanashi, 12.vii.1996; 1 male, Minano, Saitama, 27.v.1975; 1 female, Urawa, Saitama, 24.v.1975; 1 female, Mikashima, Tokorozawa city, Saitama, 19.vii. 1990; 1 male, Koajiro, Kanagawa, 2.v.1995; 1 female, Sengokubara, Hakone-cho, Kanagawa, 18.vii.1997; 1 male, Ashikubo, Shizuoka city, Shizuoka, 5.vii.1958 (NIAES); 1 female, Mizutani, Taga-cho, Shiga, 6.v.1997; 1 male, Uchikubo, Kyôto, 4.v.1997;2 males, Mt. Myôkensan, Toyono-cho, Osaka, 6.v.1996, 13.vi.1997; 1 female, Tosaka, Ishijima-cho, Hyôgo, 27.iv.1997. [Shikoku] 12 males, 2 females, Tsuchigoya, Omogo, Emime, 9-12.viii. 1998. [Kyushu] 4 males, 2 females, Mt. Sefuri, Fukuoka, 6.vi.1995, 18, 29.vi, 26.viii.1997; 1 male, Mt. Washiodake, Yamagawa-cho, 17.v.1996; 1 male, Mt. Inao, Sata-cho, Kagoshima, 23.vii.1997; 1 male, Anbô, Is. Yaku, Kagoshima, 29.viii.1963; 1 male, Nishinakama, Is. Amami, Kagoshima, 29.v.1993; 1 female, Nabeguro, Kasari-cho, Is. Amami, Kagoshima, 9.vii.1997. [Ryukyus] 2 males, 4 females, Is. Ryukyu, 26.iii., 29.iv., 2, 6, 7.v.1953 (NIAES); 1 female, Shoshi, Is. Okinawa, 29.vi.1982. KOREA. 2 males, Imjim-gak, P'ajv-gun, Kyonggi-do, 8.vii.1998. TAIWAN. [Nantû] 2 females, Tungyenchi (950m), Meichi, Jenai-hsiang, 19.xi.1997 (all in BLKU except as indicated).

Distribution. Japan (Hokkaido, Honshu, Shikoku*, Kyushu*, Ryukyus*); Taiwan*, Korea*, Europe northwards to S. England, N. Germany, N. Poland, St. Petersburg, Transcaucasia and Russia (S. Siberia, Ussuria). 
Host. LEPIDOPTERA: Noctuidae, Plusia festucae (Linnaeus) [Ashikubo, Shizuoka city] (BLKU); Pseudaletia separata (Walker) [Nishinasuno, Tochigi] (Shima, 1999).

Remarks. This species is widely distributed and common in Japan. This species is similar to $C$. dorsigera, but is easily distinguished from it by the light yellow thoracic dorsum.

The following species are treated as incertae sedis in this paper.
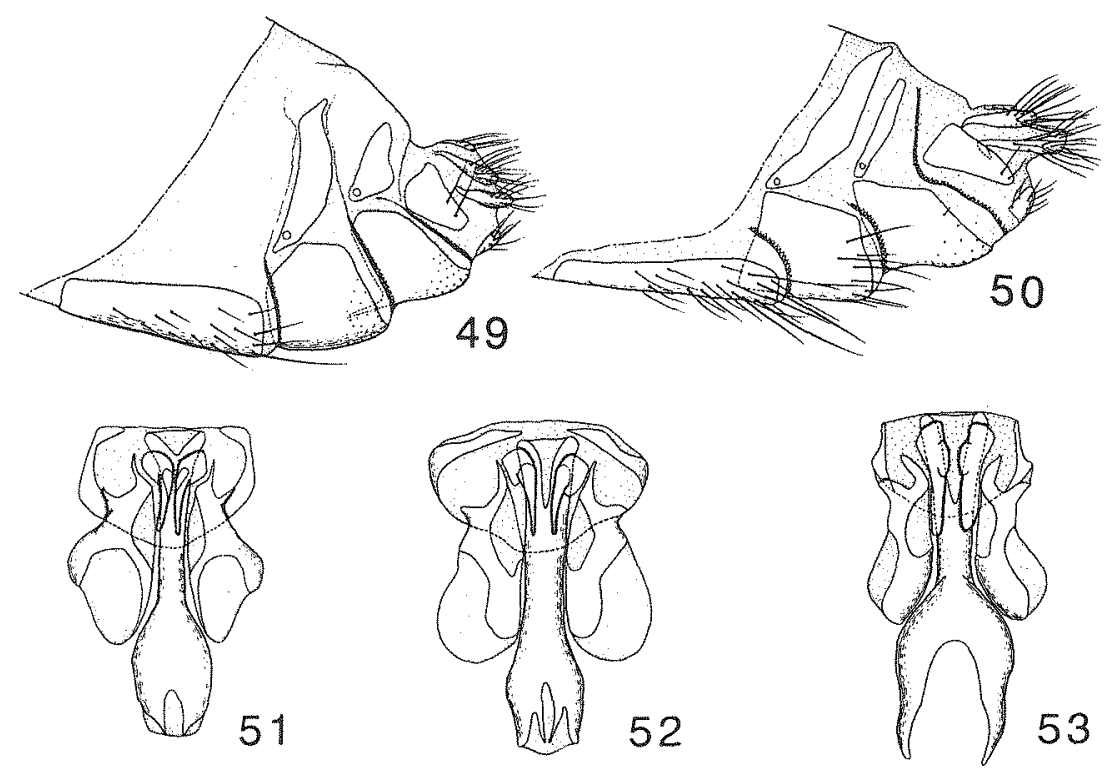

Tigs 49-50. Female terminalia in lateral view. - 49. C. silacea; 50. C. cothurnata. Figs 51-53. Hypandria, gonopods, parameres, and distiphalli in dorsal view. - 51. C. prominula; 52. C. glaucescens; 53. C. pendleburyi.

\section{Ceromya cothumata sp. m.}

(Figs 4, 11, 19, 27, 35, 43, 50, 62, 63)

Diagnosis. Thoracic dorsum gray, with yellow pollinosity, $3+3 \mathrm{dc} ; R_{1}$ bare; $R_{4+5}$ setulose dorsally to beyond level of crossvein dm-cu; $\mathrm{CuA}_{1}$ bare.

Description. Male. Head. Whitish-yellow in ground color; fronto-orbital plate yellow, with golden pollinosity; antenna with scape, pedicel, and basal $1 / 3$ of 1 st flagellomere yellow, brownish yellow on apical $2 / 3 ; 2$ nd and half of 3 rd aristomere light yellow, black on apical $1 / 2$ of 3rd; frontal vitta light orange; palpus light yellow. Vertex about 0.35 of head width; parafacial slightly narrower than length of 2 nd aristomere at middle height; gena about 0.25 of eyeheight; 5 frontal setae; anterior seta near middle of fronto-orbital plate, thick and about twice as long as posterior seta; antenna with 1st flagellomere rectangular, 2-2.3 times as long as wide and 4.2-5 times as long as pedicel; 2 nd aristomere about 2 times as long as wide; 3rd aristomere thickened on basal 3/7; prementum normal, about 4 times as long as wide.

Thorax. Dorsum gray, with yellow pollinosity; postpronotal lobe and pleura light yellow, with yellow pollinosity; scutellum grayish-yellow. $3+3 \mathrm{dc}$; subapical scutellar seta about 2.3 times as long as scutellum. 


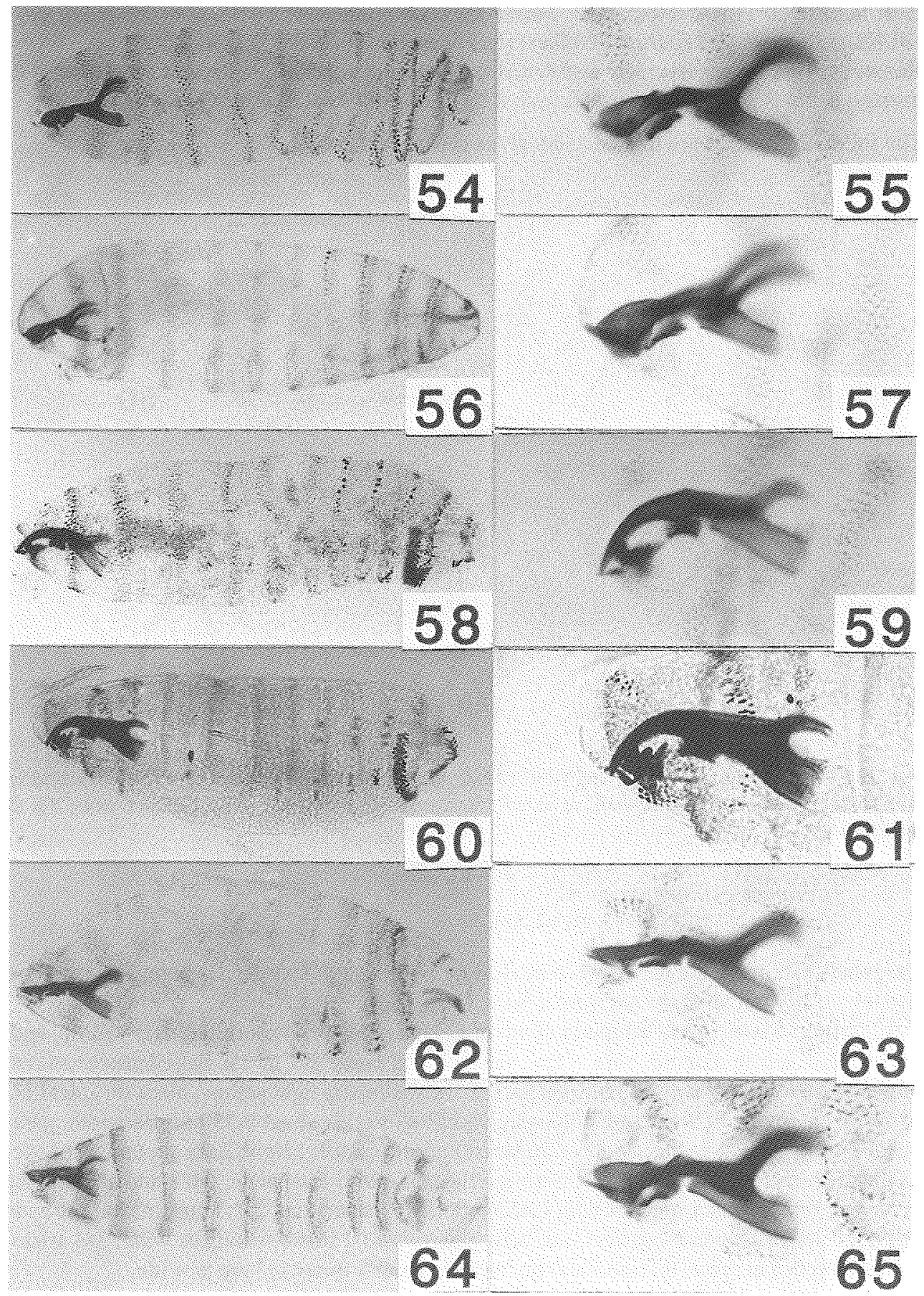

Tigs 54-65. First instar larvae and cephalopharyngeal skeletons in lateral view, - 54, 55. C. bicolor; 56 , 57. C. flaviseta; 58, 59. C. silacea; 60,61. C. dorsigera; 62, 63. C. cothurnata; 64, 65. C. luteola. 
Wing. Hyaline; tegula black, basicosta light yellow. Relative lengths of costal sectors 2nd, 3rd, and 4th approximately as $2: 7: 3.5$; ultimate section of $\mathrm{CuA}_{1}$ 0.28-0.32 times as long as penultimate section, and 1.1-1.3 times as long as crossvein dm-cu; $R_{1}$ bare; $R_{4+5}$ setulose dorsally to beyond level of crossvein $\mathrm{dm}-\mathrm{cu} ; \mathrm{CuA}_{1}$ bare.

Legs. Fore tibia with 1-2 pd setae; mid femur with 1 preapical ad seta.

Abdomen. Yellow in ground color, almost without pollinosity; terga 3-4 with black median subtriangular spot and pair of lateral spots, lateral spots of tergum 4 larger than those of 3rd. Syntergum 1+2 with pair of lateral marginal setae; terga 3-4 with pair of lateral discal setae; sternum 5 similar to $C$. pendleburyi.

Male genitalia. Surstylus fused with epandrium at base, in lateral view boot-like, curved vertically at apex, in dorsal view widened on basal $1 / 3$; cerci in lateral view slightly shorter than surstylus, with tuft of long setae on apical $2 / 5$, and in dorsal view very narrow on apical half; paramere similar to C. pendleburyi; gonopod in lateral view sickle-like posteriorly, lateral edge pointed apically; epiphallus absent; distiphallus in lateral view broad sclerotized, with small spinules ventrally, in dorsal view two narrow lobes projected apically, each lobe pointed at apex.

Female. Similar to male, but differing as follows: antenna with 1st flagellomere slightly slender, about 2 times as long as wide and 4-4.5 as long as pedicel.

Female terminalia. Similar to C. helvola, differing as follows: sternum 6 with some long setae; tergum 7 present as narrow hemitergite; sternum 7 with minute setulae; spiracles 6-7 present on each tergum, respectively.

First instar larva. Labrum somewhat broad apically; lateral sclerite long and slender; hypopharyngeal region with distinct roof of food canal; hypopharyngeal sclerite long and slender; dorsal cornu relatively long and broad; ventral cornu broad; segment 6 with some tiny spinules dorsally and ventrally; segment 7 with rows of spinules ventrally.

Body length. 4.5-5.0 mm.

Holotype male, Kamitoshibetu, Ashoro-cho, Hokkaido, Japan, 16.viii.1996, T. Tachi (BLKU). Paratypes. JAPAN [Hokkaido] 1 male, same locality as holotype, 17.viii.1996, T. Tachi; 2 females, Akankohan spa, Akan-cho, 11.ix.1997, T. Nakamura; 2 females, Onnetoh Lake, Ashoro-cho, 15.ix.1997, T. Nakamura; 1 female, Oketo-rindô, Kamishihoro-cho, 26.vi.1997, R. Matsumoto; 1 female, Miyaginosawa, Sapporo city, 20.viii.1997, M. Sueyoshi. [Honshu] 1 female, Hiraniwa, Yamagara village, Iwate, 15.viii.1997, M. Sueyoshi; 1 female, Yokose, Saitama, 25.ix.1977, K. Hara (all in BLKU).

Etymology. This species is named for the shape of surstylus.

Distribution. Japan (Hokkaido, Honshu).

Host. Unknown.

Remarks. This species is similar to members of the $C$. silacea group, but differs from them in that the female abdominal sternum 7 has only minute setulae and labrum of 1st instar larva is somewhat broad apically.

\section{Ceromya luteola sp. n.}

(Figs 12, 20, 28, 36, 44, 64, 65)

Diagnosis. Thoracic dorsum yellow; tegula light yellow; vertex 0.39-0.42 of head width; $3+4$ $\mathrm{dc} ; \mathrm{R}_{1}$ bare; $\mathrm{R}_{4+5}$ setulose dorsally to slightly beyond level of crossvein dm-cu; $\mathrm{CuA}_{1}$ bare. Description. Male. Head. Whitish-yellow in ground color; fronto-orbital plate yellow with golden pollinosity; frontal vitta light yellow to yellow; ocellar triangle black; antenna with scape, pedicel, and 1st flagellomere yellow; 2nd and 3rd aristomeres orange on basal half, 
brown on apical half. Vertex $0.39-0.42$ of head width; parafacial wider than length of 2 nd aristomere at middle height; gena $0.3-0.35$ of eye-height; 5 frontal setae; anterior reclinate orbital seta situated posterior to middle of fronto-orbital plate, short and about 1.5 times as long as posterior seta; antenna with 1st flagellomere suboval, 1.6-1.8 times as long as wide and 3.3-4.2 times as long as pedicel; 2 nd aristomere about twice as long as wide; 3 rd aristomere thickened on basal 2/5-1/2; prementum normal, about 3.5 times as long as wide.

Thorax. Dorsum yellow, with golden pollinosity; pleura light yellow. $3+4 \mathrm{dc}$; subapical scutellar seta about 2.5 times as long as scutellum.

Wing. Hyaline; tegula and basicosta light yellow. Relative lengths of costal sectors $2 \mathrm{nd}$, 3rd, and 4th approximately as 2: 9: 4; ultimate section of $\mathrm{CuA}_{1}$ about 0.28 times as long as penultimate section, and subequal in length to crossvein dm-cu; $R_{1}$ bare; $R_{4+5}$ setulose dorsally to slightly beyond level of crossvein $\mathrm{dm}-\mathrm{cu} ; \mathrm{CuA}_{1}$ bare.

Legs. Mid femur with 1 preapical ad seta; hind tibia with 4-5 ad and 3-5 pd setae of unequal lengths, and 4-5 v setae.

Abdomen. Yellow in ground color, almost without pollinosity. Tergum 4 with black oval median spot and pair of lateral black spots; terga 3-5 with indistinct black mid-dorsal longitudinal vitta in some specimens. Syntergum 1+2 with pair of lateral marginal setae; terga 3-4 with pair of lateral discal setae; sternum 5 with pair of elongate median lobes, flattened on inner edge; pair of accessory lobes slightly developed on inner edge.

Male genitalia. Surstylus fused with epandrium at base, with setae at middle, in lateral view broadened apically; cerci in lateral view nearly straight, slightly shorter than surstylus; paramere slightly bifurcated apically; gonopod with large membranous area bearing spines; epiphallus present; distiphallus in lateral view almost sclerotized, ventral portion weakly sclerotized, with some small spinules.

Female. Similar to male, but differing as follows: antenna with 1st flagellomere rectangular, about 2 times as long as wide.

Female terminalia. Similar to C. kurahashii, hypoproct slightly bent backward above tergum 8 . First instar larva. Labrum broad apically; lateral sclerite long and slender; hypopharyngeal region with distinct roof of food canal; hypopharyngeal sclerite long and slender; dorsal cornu relatively long; ventral cornu broad; each segment with several rows of tiny spinules ventrally. Body length. 4.5-5.0 mm.

Holotype male, Yunosawa tôge, Yamato village, Yamanashi, Honshu, Japan, 18.vii.1996, T. Tachi (BLKU).

Paratypes. JAPAN [Honshu] 1 female, Mt. Iwate, 2.viii.1975, O. Yata; 1 female, Tazawakokôgen, Akita, 20.vi.1974, S. Fukushi; 1 male, Yumoto, Tochigi, 26.vii.1973, K. Kanmiya; 1 male, 1 female, same locality as holotype, 17.vii.(at light), 18.vii.1996; 2 males, Mt. Kanayama, Sudama-cho, Yamanashi, 19.vii.1975 (malaise trap), J. Emoto; 1 female, Ochiai, Sudama-cho, Yamanashi, 16.vii.1996, T. Tachi (all in BLKU).

Etymology. This species is named for the yellow body.

Distribution. Japan (Honshu).

Host. Unknown.

Remarks. We treat this species here as incertae sedis because the general appearance of the genital structures do not fit well in to any of the treated species groups. This species resembles C. kurahashii, but is distinguished from it by the wide vertex and light yellow tegula.

\section{Acknowledgments}

We are grateful to Assis. Prof. B. J. SINCLAIR (BLKU) for his critical review of an early draft of this paper, and to Drs. H.-P. TSCHORSNIG (SMSC), Dr. J. ZIEGLER (DEI), and J. E. O'HARA (CNC) for loans 
of valuable specimens. One of us, TACHI wishes to express his thanks to Prof. T. SAIGUSA and Assoc. Prof. O. YATA (BLKU) for constant guidance and encouragement. We also are much indebted to the following entomologists for offering specimens: Dr. T. NAKAMURA (Tochigi Prefectural Museum), Mr. R. Matsumoto (Osaka Museum of Natural History), Mr. K. Masunaga, Mr. H. Suenaga, Mr. M. SUEYOSHI, Mr. K. ODAGIRI and Mr. M. YAGO (BLKU).

\section{References}

ANDERSEN, S. 1996: The Siphonini (Diptera: Tachinidae) of Europe. - Fauna Entomologica Scandinavica 33: 1-146.

COQUILIETT, D. W. 1910: The type-species of the North American genera of Diptera. - Proceedings of the United States National Museum 37: 499-647.

CROSSKEY, R. W. 1976: A taxonomic conspectus of the Tachinidae (Diptera) of the Oriental Region. Bulletin of the British Museum (Natural History). Entomology Supplement 26: 1-357.

Crosskey, R. W. 1977: Family Tachinidae. - In: DELFInALDO, M. D. \& HARDY, D. E. A Catalog of the Diptera of the Oriental Region. Suborder Cyclorrhapha (excluding Division Aschiza) 3: 586-697. The University Press of Hawaii, Honolulu.

HERTING, B. 1967: Beiträge zur Kenntnis der europäischen Raupenfliegen (Dipt. Tachinidae). X. Stuttgarter Beiträge zur Naturkunde (A) 173: 1-11.

HERTING, B. 1984: Catalogue of Palearctic Tachinidae (Diptera). - Stuttgarter Beiträge zur Naturkunde (A) 369:1-228.

MALLOCH, J. R. 1926: Notes on Oriental Diptera, with descriptions of new species. - Philippine Journal of Science 31: 491-512.

MALloch, J. R. 1930: Diptera Calyptratae of the Federated Malay States. - Journal of the Federated Malay States Museums 16: 119-153.

MALloch, J. R. 1935: Diptera Calyptratae chiefly from Malaya and North Borneo. - Journal of the Federated Malay States Museums 17: 646-685.

MEIGEN, J. W. 1824: Systematische Beschreibung der bekannten europäischen zweiflügeligen Insekten 4, xii+428 pp. Hamm.

MESNIL, L. P. 1953: Nouveaux Tachinaires d'Orient (1re partie). - Bulletin et Annales de la Société Entomologique de Belgique 89: 85-114.

MESNIL, L. P. 1957: Nouveaux Tachinaires d'Orient (Deuxième série). - Mémoires de la Société Royale d'Entomologie de Belgique 28: 1-80.

MesnIL, L. P. 1963: Larvaevorinae (Tachininae). - In LINDNER (ed.) Die Fliegen der Palaearktischen Region 64 g: 813-828. E. Schweizerbart'sche Verlagsbuchhandlung, Stuttgart.

O'HARA, J. E. 1988: Survey of first instars of the Siphonini (Diptera: Tachinidae). - Entomologica Scandinavica 18: 367-382.

O'HARA, J. E. 1989: Systematics of the genus group taxa of the Siphonini (Diptera: Tachinidae). Quaestiones Entomologicae 25: 1-229.

O'HARA, J. E. 1994: Revision of Nearctic species of Ceromya ROBINEAU-DESVOIDY (Diptera: Tachinidae). - Canadian Entomologist 126: 775-806.

Richter, V. A. 1993: New and little-known Tachinidae (Diptera) from Transbaikalia and the Far East. Entomologischeskoye Obozreniye 72 (2): $422-440$ [In Russian, English translation in Entomological Review 74 (1995) (6): 64-83].

RoBINEAU-Desvoidy, J. B. 1830: Essai sur les Myodaires. Mémoires présentés par divers Savans à l'Académie Royale des Sciences de l'Institut de France. Sciences Mathématiques et Physiques 2: 1813. Paris.

SHIMA, H. 1970: Notes on some Japanese Siphonini (Diptera: Tachinidae). - Journal of the Faculty of Agriculture, Kyushu University 16 (2): 179-192.

SHMA, H. 1973: New host records of Japanese Tachinidae (Diptera: Calyptrata). Sieboldia 4 (3): 153160. 
SHIMA, H, 1996: A systematic study of the tribe Winthemiini from Japan (Diptera, Tachinidae). Beiträge zur Entomologie 46 (1): 169-235.

SHIMA, H. 1999: Host-parasite catalog of Japanese Tachinidae (Diptera). - Acta Dipterologica. Supplement 1: 1-108.

TACHI, T. \& SHIMA, H. 1998: A systematic study of the genus Actia RoBINEAU-DesvoIDY of Japan (Diptera: Tachinidae), - Entomological Science 1 (3): 441-463.

\section{Author's address:}

TAKUJI TACHI \& HIROSHI SHIMA

Biosystematics Laboratory

Graduate School of Social and Cultural Studies

Kyushu University, Ropponmatsu

Fukuoka, 810-8560, Japan

\section{Besprechungen}

Die Eichenschädlinge und ihre Feinde / PATOČKA, J.; KRIŠTín, A.; KULFAN, J. \& ZACH, P. (Hrsg.). Institut für Waldökologie der Slowakischen Akademie der Wissenschaften Zvolen 1999. - 396 S., 114 Farb-, 85 schw./w. Abb. - 58.- DM

Es ist erfreulich, dass endlich ein zusammenfassendes Werk erscheinen konnte. Die jahrelangen Forschungen eines Teils der 15 Autoren konnten bis 1990 aus politischen Gründen nur teilweise und unter großen Schwierigkeiten veröffentlicht werden, obwohl die Problematik der Erhaltung unserer Eichenwälder ein dringendes und europäisches Problem ist.

Diskutiert werden die ökologischen Ansprüche der im slowakischen Gebiet vorkommenden Arten unter besonderer Berücksichtigung der überwiegend vertretenen Stiel- und Traubeneichen. Die Ursachen des Eichensterbens bilden veränderte abiotische Faktoren, die oft Voraussetzung für umfangreiche Schäden durch Insekten sind. Im umfangreichen vierten Kapitel werden alle, vor allem im Kronenbereich ermittelten Arthropodenarten, übersichtlich aufgelistet. Für Parasitoide werden entsprechende Wirte verzeichnet. Umfassend wird auf Käfer und Schmetterlinge eingegangen und zu letzteren eine Bestimmungstabelle der erwachsenen blattfressenden Raupen gegeben. Diese wird durch zahlreiche hervorragende Farbbilder ergänzt.

Neben kurzen Bemerkungen zu rein chemischen und biologischen Bekämpfungsmethoden wird im Rahmen eines integrierten Forstschutzes ausführlich auf Monitoring und Prognose besonders der Blattfresser eingegangen. Größerer Raum wird auch den Feinden der Eichenschädlinge mit $z$. T. sehr detaillierten Untersuchungsergebnissen eingeräumt. Dabei werden pathogene Viren, Bakterien, Pilze, Protozoen und Fadenwürmer sowie entomophage Insekten und Prädatoren (einschließlich Vögel und Säuger) einbezogen.

Das letzte Kapitel beschäftigt sich mit Vorschlägen der Bewirtschaftung. Besondere Berücksichtigung finden auch Fragen der Resistenz gegen schädliche Insekten.

Das Literaturverzeichnis umfasst fast 500 Titel. Leider wird im Index kein Artenverzeichnis ausgewiesen, was bei der nicht immer auf dem neuesten Stand befindlichen Nomenklatur sicherlich von Nachteil ist. Wenn auch nicht alle Fakten auf alle europäischen Verhältnisse übertragbar sind, handelt es sich doch bei dem Buch um ein empfehlenswertes Standardwerk, das nicht nur der Praxis, sondern auch in der Forschung wichtige Grundlagen bietet.

Die Arbeit kann über das Institut für Waldökologie der Slowakischen Akademie der Wissenschaften, Stúrova 2, Zvolen, SK- 960 53, Slowakei bezogen werden. 